\title{
Lean practices and the adoption of digital technologies in production
}

\section{Robin von Haartman*, Lars Bengtsson and Camilla Niss}

\author{
Department of Industrial Management, Industrial Design \\ and Mechanical Engineering, \\ University of Gävle, \\ 80176 Gävle, Sweden \\ Email: robin.vonhaartman@hig.se \\ Email: lars.bengtsson@hig.se \\ Email: camilla.niss@hig.se \\ *Corresponding author
}

\begin{abstract}
The use of Lean principles has long enabled the improvement of efficiency and competitiveness in manufacturing firms, but during the last decade, advanced digital and automated solutions have been more in the spotlight. It has been suggested by some authors that Lean and digitalisation are mutually exclusive, although most authors now agree that the two are indeed compatible. It thus seems that the most urgent question is not whether Lean and digital technologies can be combined, but rather how. This paper uses a large-scale survey of manufacturing units in Europe to explore the relationship between three types of Lean production practices and the use of digital technologies in production. The analysis shows that three types of Lean practices - Lean flow, Lean work organisation and Lean human resource management - are strongly associated with firms' adoption of digital technologies in production by manufacturing firms. Based on the results it is suggested that, as a theoretical explanation, a firm's experience of Lean may act as an absorptive capacity when adopting digital technologies. A number of practical explanations are also provided, e.g., that systematic improvement efforts are also beneficial when implementing digital technologies.
\end{abstract}

Keywords: digitalisation; Lean practices; manufacturing strategy; absorptive capacity; Industry 4.0.

Reference to this paper should be made as follows: von Haartman, R., Bengtsson, L. and Niss, C. (2021) 'Lean practices and the adoption of digital technologies in production', Int. J. Services and Operations Management, Vol. 40, No. 2, pp.286-304.

Biographical notes: Robin von Haartman is an Associate Professor of Logistics and Supply Chain Management at the University of Gävle, Sweden. His areas of interest include manufacturing strategy\&, strategic sourcing, logistics and sustainability.

Lars Bengtsson is a Professor of Innovation Management at the University of Gävle, Sweden. His research focuses on open innovation and knowledge integration, manufacturing strategies and outsourcing, and human Lean and digitalisation. 
Camilla Niss is an Assistant Professor in Industrial Management at the University of Gävle, Sweden. Her research interests include innovation, digitalisation, project management and Lean.

This paper is a revised and expanded version of a paper entitled 'Lean practices as requisites for the use of digital technology in production and digital or lean? Analyzing configurations and best practice in European manufacturing firms' presented at 23rd EurOMA Conference, Trondheim, Norway and the 5th World Conference on P\&OM, Havana, Cuba, 5-10 September 2016.

\section{Introduction}

Lean production principles have long been hailed as a solution for improving efficiency and competitiveness in manufacturing firms (Marley and Ward, 2013). But while the use of Lean principles has enabled the improvement of productivity, quality and customer service in many organisations, it has also been argued that the use of IT has led to similar benefits (Riezebos et al., 2009), and during the last decade advanced digital and automated solutions have been more in the spotlight. Indeed, some say that at present, "a far-reaching technology push in industrial production can be observed" [Hirsch-Kreinsen, (2016), p.1]. This new era is described in terms of a fourth industrial revolution, also known as 'Industry 4.0' in Germany. One definition of the fourth industrial revolution is "the introduction of internet technology in the manufacturing industry to render factories more intelligent; increase adaptability, resource efficiency, and ergonomics; and integrate customers more closely into the product definition stage as well as business partners into the value and logistic chains" [Stork, (2015), p.21]. The rapidly growing research interest in technologies and applications related to Industry 4.0 has been underlined in a recent literature review by $\mathrm{Lu}$ (2017), who identified five research categories, of which interoperability is assessed as critical.

Drawing from this trend, one may ask if this increased focus on digital solutions means that the era of Lean is over or if it is changing character. Here, we may recall that the development of the Toyota Production System was made in contrast to Western companies' reliance on IT and automation for competitive advantage (Riezebos et al., 2009). Instead of using IT in production logistics, which could lead to unnecessary cost, over-production and uncertainty, Toyota introduced Kanban systems due to their robustness and simplicity. Another example was put forward by Powell (2013) (referring to Halgari et al., 2011), where ERP systems have been seen as hindering Lean manufacturing, encouraging large inventories and leading to slow production. It has thus been suggested by some authors that Lean and digitalisation are mutually exclusive (Riezebos et al., 2009) or even clash (Hirsch-Kreinsen, 2016), although most authors now agree that the two are indeed compatible (Rüttimann and Stöckli, 2016). For example, Kolberg and Zühlke (2015) illustrate that the standardised, transparent and essential production processes of Lean production can be combined with Industry 4.0 technologies. Based on a review of literature about Lean production and Industry 4.0, Mrugalska and Wyrwicka (2017) similarly assert that the two approaches can support each other. In a systematic analysis of Lean shortcomings regarding integration, Sanders et al. (2016) further claim that technologies associated with Industry 4.0 may provide a 
solution to the shortcomings of Lean. It thus seems that the most urgent question is not whether Lean and digital technologies can be combined, but rather how. Although there have been some attempts to conceptually link Lean with Industry 4.0. (e.g., Sony, 2018), there are still relatively few quantitative studies showing how different dimensions of Lean actually relate to digital technologies used in production (Buer et al., 2018). In a well-designed study, Rossini et al. (2019) analysed how the adoption of a broad range of technologies relates to the level of Lean implementation in a relatively small sample of mostly Italian companies. However, the study did not analyse how different dimensions of Lean explain the use of technologies.

A problem with measuring Industry 4.0 technologies is that they are widely used by a very small number of companies, making statistical analysis problematic. The purpose of this study is therefore to explore the relationship between the simultaneous use of Lean practices and established digital technological practices in production. The results of the study bring clarity to the relationship between present digital technologies in production and Lean practices and may also serve as a basis for discussing potential challenges and opportunities of combining Lean and future digital technologies.

The paper relies on the European Manufacturing Survey (EMS), a large-scale survey of manufacturing sites in Europe. The paper uses data from Austria, France, Spain, Croatia, Slovenia, Portugal and Sweden. The data was collected in 2012-2013 and the total useable sample size is 548 . The data is analysed using means testing, correlation analysis, nonlinear principal component analysis (PCA) and regression analysis. The paper is organised as follows: the first section briefly covers the theoretical underpinnings of the paper and presents research questions. The second section outlines the methodology in more detail, section three reports results, section four includes a discussion, and finally in the fifth section, conclusions are presented.

\section{Theoretical framework}

\subsection{Lean production}

Lean production originates from the management system of Toyota Motor Corporation, also known as the Toyota Production System (Liker, 2004). Inspired by the success of Toyota, the concept of Lean has spread all over the world and been applied in various processes and sectors (Marley and Ward, 2013; Bhutta et al., 2017). Over time the concept has evolved and been defined in many ways (Pettersen, 2009; Emiliani, 2006; Stone, 2012). While early key objectives for Toyota were "production efficiency by consistently and thoroughly eliminating waste", Emiliani (2006, p.169) claims that later Toyota states that 'continuous improvements' and 'respect for people' are the main principles. The focus on continuous improvements and kaizen are also stressed by many others (e.g., Imai, 1997: Marley and Ward, 2013). The many ways to understand Lean have also been recognised in papers that evaluate models for Lean manufacturing (Khalili et al., 2017) and provide overviews of previous Lean studies (e.g., Holweg, 2007; Bhamu and Sangwan, 2016). The latter studies show that Lean has been described both as a number of practices and a philosophy, and that Lean covers both an operational and a strategic dimension (e.g., Shah and Ward, 2003, 2007; Hines et al., 2004; Pettersen, 2009). The principles of Lean have also been applied in processes outside production, such as Lean supply (Lamming, 1996), Lean supply chain (Galankashi and Helmi, 2017), 
Lean product development (Liker and Morgan, 2006), Lean knowledge work (McDermott and Venditti, 2015), Lean enterprise (Murman et al., 2002) as well as Lean healthcare (Augusto and Tortorella, 2019).

The great variety in interpretation becomes further evident when scrutinising existing frameworks that aim at describing the status of Lean in firms and organisations (Yadav et al., 2019; Cocca et al., 2019). As an example, Karlsson and Åhlström (1996) defined Lean as based on five fundamental principles: multifunctional teams, vertical information systems, networks, and no buffers or indirect resources, which have different expressions in different functional areas. Liker (2004) describes Lean in terms of 14 principles grouped into four P's: philosophy, process, people and partners, and problem solving. Two of the most influential studies are presented by Shah and Ward $(2003,2007)$. In the prior study they identified 22 Lean practices that empirically formed four bundles that together describe firms' approaches to Lean manufacturing: just in time (JIT), total quality management (TQM), total productive maintenance (TPM) and human resource management (HRM). In Shah and Ward's study from 2007 they added a value chain perspective. They identified 48 Lean practices/tools that in practice formed 10 distinct factors/dimensions (each one built up by three to six practices) and together constitute an operational definition of Lean production. The factors relate to supplier involvement (three factors), customer involvement (one factor) and internal conditions (six factors). The latter factors concern pull, continuous flow, low setup time, controlled processes, TPM and employee involvement.

The varying approaches and principles for describing Lean indicate that competitive Lean practices change over time. Effective practices commonly become internalised, while ineffective practices are erased and new practices become differentiating. As an example, the practices of TQM are widespread today and do not solely characterise a front-line Lean enterprise. At the other end, later studies have, in contrast to Shah and Ward (2007), stressed the human side of Lean (e.g., Emiliani, 2006; Liker, 2004), expressed in practices such as team-based work and improvements in daily work.

While there is a lack of consensus on how to describe and measure Lean, in this study we have chosen to combine a selection of practices suggested by Shah and Ward (2007) with practices from Liker (2004) that cover the dimensions of people and problem solving. We further limit the study to operational practices of Lean applied in manufacturing. The items used in our analysis are further specified in the methods section.

\subsection{Combining Lean practices and digital technologies}

It is clear that the level of digitalisation differs between different industries (Gandhi et al., 2016; Strategy\&, 2013) and company size (Strategy\&, 2013). In this paper, we focus broadly on manufacturing (NACE 10-33) and production sites with more than 20 employees. We also focus on the empirical usage of digital technologies associated with 'late stage Industry 3.0'. By late stage we refer to technologies that go beyond digital technologies known as computer integrated manufacturing (CIM) systems (i.e., the use and integration of CNC machines, robots, FMS systems, CADCAM systems, EDI systems, etc.). CIM systems were mainly established during the 1970s and 1980s. Specifically, we focus both on 
1 digital simulation systems that build upon CIM technologies, such as virtual reality systems for product and process design and simulation

2 digital administrative systems used to support a seamless development process, such as product lifecycle management (PLM) systems, supply chain management systems and idea management systems.

As mentioned above, there has been a debate about whether or not Lean and IT can be successfully combined (Powell et al., 2013). Buer et al. (2018) note that many digital technologies facilitate distributed computing and autonomy, which matches well with the decentralised structures and low levels of complexity favoured by Lean thinking. Riezebos et al. (2009) suggest that due to an increasing acceptance of Lean production, lately 'hybrid production systems' are used that, consistent with Lean production principles, combine elements from several systems [Riezebos et al., (2009), p.245]. In an editorial on how IT may help to advance Lean manufacturing, Riezebos and Klingenberg (2009) conclude that IT systems facilitate the application of Lean production concepts, for example pull control. They also list some other beneficial areas of IT systems, e.g., that they may increase the effectiveness of employee training programs and also support practitioners when deciding on forthcoming steps in the implementation of Lean production.

Marvel and Standridge (2009) discuss a contradiction in Lean: whereas Lean relies on iterations to 'perfect' a process, as part of continuous improvement, this takes time, which is a form of waste. The solution is to use simulation to make the process development leaner, by ensuring the changes being made are beneficial before actually implementing them. Abdulmalek and Raigopal (2007) describe a case where simulations were used in order to assess the advantages of adopting Lean techniques in manufacturing.

According to Liker and Burr (1999), Toyota's production system uses surprisingly little digital technology, but they also acknowledge that these technologies can serve as a powerful tool to aid Lean implementation, as long as they are designed to be subordinate to the existing physical systems and not to replace them. They also acknowledge that the role of digital technologies is on the increase due to increased complexity of many products, multiple products on an assembly line and the difficulty in forecasting customer demand. As practical examples of where digital technologies can aid Lean, Liker and Burr (1999) suggest decisions on optimal batch sizes and the levelling of production.

When analysing data on the use of internal and external IT and the adoption of Lean production of first-tier suppliers in the Spanish automotive industry, Moyano-Fuentes et al. (2012) found that the degree of using internal IT - but not external IT - is positively associated with the adoption level of Lean practices. The internal IT systems they referred to were computer-aided engineering and manufacturing systems such as CAD, CAM, CAE, CAPP, FMS and ERP. The Lean production variables were, according to Moyano-Fuentes et al. (2012): location of machines and nearby processes in plant; manufacturing cells; layout that permits reduced inventory levels and faster manufacturing; TQM; SMED; time every day to plan equipment maintenance-related activities; regular maintenance on all equipment; JIT; and Kanban. Drawing from their results, they argue that in their internal core processes companies should develop internal IT to be more explicitly associated with the efficiency aimed for by Lean practices (Moyano-Fuentes et al., 2012). Some other studies have analysed the relationship between Lean practices and specific digital technologies, which we summarise in the 
following two sections, focusing on digital simulation systems and digital administrative systems.

\subsubsection{Lean practices and digital simulation systems}

In terms of digital simulation systems, tools that integrate technologies for product and process development, plant design and operative production planning into a whole simulation system - the 'digital factory' - have been developed (Kuehn, 2006). Moreover, recent research shows the growing potential of how to use technologies to realise Industry 4.0, when it to comes to more efficient processes (Lu, 2017) and also Lean product development (Rauch et al., 2016). Using digital factory systems means that the whole factory can be simulated as a virtual-reality model and applied from the product idea to the dismantling of the production plants (Bracht and Masurat, 2005). When discussing the relation between Lean and the digital factory, it has been explicitly argued that the digital factory may help to facilitate six sigma and Lean initiatives since such systems can allow the analysis of variation in a graphical environment (Kuehn, 2006).

It has also been argued that a Lean production philosophy should be adopted when using and developing a 'factory-of-things' (Zuehlke, 2010). Zuehlke argues that while we are using computer-integrated manufacturing, planning and operations still involve great complexity. This, he argues, is due to the fact that planning processes still are, e.g., too sequential, hardware and product-specific. There are also challenges of individualised products, global competition, shorter product life cycles and short time-to-market adjustments. Arguing that Lean implies complexity reduction, avoidance of waste, unnecessary technologies and information, and support of human daily work, Zuehlke (2010, p.130) thus suggests to "create and use Lean technologies now as you created a Lean organisation then."

\subsubsection{Lean practices and digital administrative systems}

In terms of combining Lean practices and various digital administrative systems, some examples are described in the following. Focusing on product life cycle management (PLM) systems as digital technologies, Gecevska et al. (2013) combine the Lean and PLM concepts. They put forward what they refer to as 'Lean PLM', arguing that if such is used, sound business decisions may be taken based on the right amount of product data throughout the product life cycle. They also argue that implementing Lean management in the product lifecycle may, e.g., lead to cost reduction, increased profitability and faster time-to-market. They further conclude that while previously being an IT system for managing data, product life cycle management has now become an IT system that supports the management of the processes based on such data. Such PLM may also facilitate data sharing and team collaboration across geographical boundaries (Gecevska et al., 2013).

Another digital administrative system discussed in relation process improvements in general (Alawamleh et al., 2018) and Lean in particular (Powell et al., 2013) is enterprise resource planning (ERP). Drawing from a literature review on ERP and Lean production, Powell (2013) states that even though the integration objective of ERP systems and the holistic approach of Lean production seem to fit, ERP systems have frequently been seen as sources of waste in Lean production literature. With reference to Halgari et al. (2011), 
Powell (2013) also stresses that ERP systems have been seen as hindering Lean manufacturing and have been criticised for supporting slow production and big inventories. When later summarising their findings, they conclude however that both Lean and ERP offer ways to increase competitiveness for manufacturers and also encourage researchers and practitioners to make use of their framework when looking into how synergies can be made by combining the two. They also explicitly suggest further research in this area, e.g., on how they can be combined for competitive advantage and methods for concurrent application.

Finally, digital idea management systems have been discussed in relation to Lean. As previously mentioned, kaizen means that improvement work in terms of small and incremental changes is performed by both managers and workers (Imai, 1997). Though the benefits of such high involvement innovation (HII) are evident, it is not easy to implement in practice (Abu El-Ella et al., 2013). Exploring how it can be realised, including exploring the managerial issues involved, Abu El-Ella et al. (2013) focus on the role of a number of new technologies, defined as technical enablers for HII, i.e., intranet suggestion systems, knowledge management systems, virtual expert communities, online idea contests and corporate social networks. Using empirical data from nine German companies from different industries and with a strong focus on product innovation, they conclude that the use of new technologies, such as corporate social networks, enabling the implementation of HII seems to be accelerating, though still at an early stage, and that the general experience thus far is positive. They also conclude that new technologies alone do not achieve HII, but that other aspects such as flexible incentive systems, top management support as well as continuous motivation of employees are necessary as complements.

\subsection{Theories to understand Lean and digitalisation}

The theoretical framework of this paper rests on the resource-based view (RBV) in which a firm's performance is mainly explained by the resources and capabilities that the firm controls (Barney, 1996). According to this view, the resources and capabilities can be seen as "bundles of tangible and intangible assets, including a firm's management skills, its organisational processes and routines, and the information and knowledge it controls" [Barney et al., (2001), p.625]. A similar way to understand this is to describe capabilities as a unique combination of the resources that the firm controls (e.g., Grant, 1996).

This line of thinking has also been adopted in previous studies of Lean. For instance, Hines et al. (2004) describe Lean as a combined capability of strategic and operational practices. One practical and theoretically important assumption made by Shah and Ward $(2003,2007)$ is also that Lean is not built up by individual practices/tools. They instead assert that Lean practices are interrelated and form Lean bundles. They also find empirical support for the view that "Lean production may be viewed as a configuration of practices/tools" and in practice "is an integrated system composed of highly inter-related elements" [Shah and Ward, (2007), p.791, p.800]. They conclude that it is the mutual interdependencies among practices that contribute to performance and make Lean production rare, valuable and difficult to imitate. In this paper we draw upon this perspective by understanding Lean as a combination (bundles) of practices aiming at obtaining resource-effective and value-based production. The practices are formed by different assets, technology and knowledge, organisational processes and managerial skills. 
Our main ambition and core question, however, does not concern how to define Lean but rather to explore how different Lean practices relate to the use of digital technologies. In order to better analyse the relationship between Lean practices and the use of digital technologies we suggest that the concept of absorptive capacity could provide a beneficial perspective. Absorptive capacity can be understood as a firm-level capability for acquiring, assimilating and exploiting external knowledge and assets (Zahra and George, 2002). This ability is based in previous investments in related knowledge or technology (Cohen and Levinthal, 1990), and consists of both specific knowledge assets and organisational mechanisms that support the transfer and integration of knowledge assets. Shenkar and Li (1999) found that firms use their absorptive capacity based on previous knowledge, to evaluate, select and integrate new complementary knowledge. von Haartman (2013) showed that manufacturing practices provide firms with an absorptive capacity for integrating customers more efficiently. We thus suggest that Lean practices increase a firm's absorptive capacity, a capacity that can be used for acquiring, assimilating and exploiting digital technologies in production, as Lean practices and digital technologies can be seen as complementary (Riezebos et al., 2009; Kolberg and Zühlke, 2015; Rüttimann and Stöckli, 2016). The team-based approach of Lean (Emiliani, 2006), will help to spread and assimilate the combined knowledge of employees, thus increasing the firm's absorptive capacity.

\subsection{Research question}

In sum, there seems to be an ongoing discussion on how Lean production and digital technologies 'fit'. Within this discussion, there is a greater focus on how digital technologies can enhance the success of Lean production, rather than exploring the potentials of organisational capabilities in terms of Lean production principles and practices (in use) when adapting to and developing digital technologies. Therefore, we aim to explore the relationship between Lean practices and the adoption of digital technologies in more detail. In this paper, we will focus on the following research question:

RQ1 What types of Lean practices are associated with the use of digital technologies in production?

\section{Methodology}

The paper relies on the EMS, a pan-European survey aimed at capturing the state of manufacturing in Europe, and was sent to production managers or persons in comparable positions. The data is collected by a consortium of universities and research institutes, and is aimed at manufacturing sites or companies (NACE Rev 2 divisions 10-33) with more than 20 employees. All countries used random sampling and a common procedure for collecting the data. The questionnaire was translated into the local language and tested for each country. Before merging the data, the datasets were subject to a joint validation and harmonisation procedure. The EMS has previously been used in publications such as Kinkel et al. (2012) and Dachs et al. (2014). We deleted all responses with missing data and ended up with a final sample size of 548. The following countries' data has been utilised in this paper (number of complete responses in parentheses): Austria (123), 
France (73), Spain (68), Croatia (103), Slovenia (58), Portugal (62) and Sweden (61). These countries provide a broad cross-section of established and emerging industrial countries in Europe. The data is analysed by correlation, nonlinear principal component and regression analyses, using SPSS software.

\subsection{Variables and constructs}

The use of digital technologies (digitalisation) in production was captured by asking the respondent to estimate the use of five practices in the manufacturing department that cover both IT systems aimed at making existing operations more efficient, as well as tools for simulating production and product development. These are understood to be the basis for using the more advanced techniques regarded as part of Industry 4.0, as well as being rather commonly used. The items for measuring the use of digital technologies in production have been iteratively developed, in collaboration between the German Fraunhofer ISI institute and industry, during five consecutive versions of the EMS, between 2001 and 2012 (Fraunhofer ISI, 2017).

The aim was to measure practices that are widely used across a wide range of industries and firm sizes. The measures of digital technology in production concern two areas: two items on virtual models of the real world and three items on administrative systems for linking the production function to other functions and the supply chain. More specifically those are: digital exchange of operations scheduling with customers/suppliers (supply chain management systems); virtual reality and/or simulation in production reconfiguration (e.g., production flows, single process steps); virtual reality and/or simulation in product design/development (e.g., digital prototyping, fem); PLM; and IT systems for storage and management of ideas (idea management systems) (Table 1). Both product and process development were thus measured as digital connectivity cuts across firms and supply chains, which is indeed one of the main characteristics of Industry 4.0 (Lu, 2017). The items were measured in two steps, the first one being if the technology is being used ( $=0$ on the scale) and then to rate to what extent, in relation to potential, the technology is being used, on a three-point scale from low (1) to high (3). This resulted in a four-point scale for each item.

Table 1 Nonlinear PCA of the use of digital technologies

\begin{tabular}{lc}
\hline & Component loading \\
\hline SC management systems & 0.65 \\
VR/simulation in production & 0.69 \\
VR/simulation in product development & 0.70 \\
PLM & 0.68 \\
Idea management systems & 0.66 \\
\hline
\end{tabular}

Notes: $\mathrm{N}=548$, total variance explained $=45 \%$, Cronbach's alpha $=0.70$.

The number of variables was reduced using nonlinear principal component analysis (NLPCA), since ordinary PCAs are only suitable for variables with interval or ratio scales (Linting et al., 2007). NLPCA achieves the same objectives as ordinary PCA, but uses a process called quantification that replaces the original values with optimally scaled ones while maximising the variance of the original variables, before the actual PCA analysis (Linting et al., 2007). The results of the NLPCA (Table 1) show that all digitalisation 
items are within one single dimension, implying that firms tend to implement them in bundles.

Lean practices were measured in the same way as the digital technologies, but consisted of 19 items covering specific Lean-related practices. As mentioned in the theory section, the investigated practices are a combination of Shah and Ward (2003, 2007) and Liker (2004). The chosen practices cover all six factors of Shah and Ward (2003) and include: value stream mapping/design; shop floor segmentation; production control by pull principles; optimising of change-over time; standardised work instruction; continuous improvement; idea generation; time for creativity/innovation; talent development program; and employee training for creativity. Inspired by Liker (2004), these practices were complemented with practices that more directly relate to daily work organisation and systems for improvements, namely: task integration; teamwork in production; visual management; quality standard (ISO 9000, etc.); and means to maintain employees and/or their knowledge. While focusing on the operational aspects of Lean we omitted practices that concern statistical process control as well as practices that are less relevant to parts of the studied industries, e.g., principles that focus on maintenance.

To reduce the number of variables, a nonlinear PCA, with Varimax rotation, was conducted. The number of components extracted was selected by observing the 'elbow' in the scree plot (Linting et al., 2007). The items were discretised using the ranking method, and missing values were excluded. All items had a variance accounted for above the 'fair' value threshold, defined as above 0.20 (Comrey, 1973). After removing one component with poor loadings on any component and four items that loaded onto several components with the secondary component loading less than 0.20 below the primary loading, three components representing broad themes emerged: flow-orientated manufacturing (flow), work organisation (Work.org) and HRM (Table 2). These three components all have acceptable component loadings and Cronbach's alpha values. It is noteworthy that one item measuring methods for continuous improvement was removed due to loading on both flow-oriented manufacturing and work organisations. The cross loading is perhaps not surprising as continuous improvement is one of the two main pillars of Lean (the other one being respect for people or HRM) (Emiliani, 2006). Many of the items in flow-oriented manufacturing and work organisations are thus implicitly part of continuous improvement.

Company size in number of employees was used as the first control variable, since previous studies have found that size has a significant impact on companies' level of digitalisation of production (e.g., European Commission, 2016). The values for number of employees are highly skewed and have a very high value for kurtosis, because there are many small firms and a small number of very large ones. A useful technique to make the data more normal is to take the logarithmic value (NIST/SEMATECH e-Handbook of Statistical Methods, 2014). We thus use the logarithmic (Ln) value of size in further analysis. The logarithmic value does indeed fall within the 'safe' limits of both skew and kurtosis, defined as between -2 and +2 (George and Mallery, 2010). The second control variable is whether the firms are in assembly-based industries, where we define the following manufacturing industries as assembly-based: computers, electronics, electrical equipment, machinery and equipment, all transport equipment and vehicles. When comparing the digitalisation degree of 15 European industries, it has been shown that what is here defined as assembly-based manufacturing (such as automotive) is more digitalised than process-based industries (such as chemistry) (Strategy\&, 2013; European 
Commission, 2016). The third control variable is whether firms use industrial robots or automation, measured on a scale from 0 (no use) to 3 (high extent of use). This serves as an indicator for the technological maturity of the company. The fourth and fifth control variables concern the region of the respondent, as later industrialisation in South and East Europe may impact both the level of Lean and digitalisation, as well as the connection between the two.

Table 2 Nonlinear PCA of Lean practices

\begin{tabular}{lccc}
\hline & Flow $\alpha=0.76$ & HRM $\alpha=0.76$ & Work.org $\alpha=0.69$ \\
\hline Value stream mapping/design & 0.71 & & \\
Shop floor segmentation & 0.55 & & \\
Prod. control by pull principles & 0.77 & & \\
Optimising of change-over time & 0.75 & & 0.76 \\
Standardised work instruction & & & 0.54 \\
Task integration & & & 0.60 \\
Teamwork in production & & & 0.35 \\
Visual management & 0.59 & & 0.70 \\
ISO 9000 & & & \\
Idea generation & & 0.59 & \\
Maintain employees/their knowledge & & 0.77 & \\
Time for creativity/innovation & & 0.74 & \\
Talent development program & & 0.60 & \\
Employee training for creativity & & 0.66 & \\
\hline
\end{tabular}

Notes: $\mathrm{N}=548$, total variance explained $=52 \%$, values under 0.35 are suppressed, $\alpha=$ Cronbach's alpha, Varimax rotation.

Table 3 Variable correlations

\begin{tabular}{|c|c|c|c|c|c|c|c|c|c|}
\hline & Flow $^{1}$ & $H R M^{1}$ & Work.org 1 & $\begin{array}{l}\text { Dig. } \\
\text { tech }^{1}\end{array}$ & $\begin{array}{l}L N \\
\text { size. }\end{array}$ & $\begin{array}{l}\text { Robots/ } \\
\text { autom. }\end{array}$ & $\begin{array}{c}\text { Assembly } \\
\text { industry }\end{array}$ & $\begin{array}{l}\text { South } \\
\text { Eur. }\end{array}$ & $\begin{array}{l}\text { East } \\
\text { Eur. }\end{array}$ \\
\hline Flow $^{1}$ & 1 & & & & & & & & \\
\hline Work.org ${ }^{1}$ & 0 & 1 & & & & & & & \\
\hline HRM1 & 0 & 0 & 1 & & & & & & \\
\hline Dig. tech ${ }^{1}$ & $0.40^{* *}$ & $0.36^{* *}$ & $0.26^{* *}$ & 1 & & & & & \\
\hline LN size ${ }^{1}$ & $0.33 * *$ & $0.27^{*}$ & 0.06 & $0.38^{* *}$ & 1 & & & & \\
\hline $\begin{array}{l}\text { Robots/ } \\
\text { autom. }\end{array}$ & $0.27 * *$ & $0.27 * *$ & 0.07 & $0.35^{* *}$ & $0.28 * *$ & 1 & & & \\
\hline $\begin{array}{l}\text { Assembly } \\
\text { industry }\end{array}$ & $0.13 * *$ & $0.16^{* *}$ & 0.05 & $0.20 * *$ & $0.19 * *$ & $0.08^{*}$ & 1 & & \\
\hline South Eur. & 0.03 & $0.12 * *$ & $0.09 *$ & 0.06 & -0.06 & 0.07 & -0.04 & 1 & \\
\hline East Eur. & $-0.21 * *$ & 0.07 & -0.06 & $0.00 *$ & 0.07 & -0.01 & 0.02 & $-0.36 * *$ & 1 \\
\hline
\end{tabular}

Notes: ${ }^{1}$ Pearson correlation, all others are Spearman correlations, ${ }^{*} \mathrm{p}<0.05,{ }^{* *} \mathrm{p}<0.01$, $\mathrm{N}=548$.

The correlations for all constructs and variables are displayed in Table 3. Note that items on ratio or interval scale use Pearson correlation, whereas the others use the non-parametric equivalent, Spearman correlation. The correlation analyses show that 
many of the items are indeed strongly correlated, although conclusions should only be drawn after a multiple regression analysis with control variables.

The potential problem of single-respondent bias has also been checked for by analysing whether all variables would load onto a single component, as recommended by Podsakoff et al. (2003), and the variables did not provide a coherent component in terms of component loadings, variance explained or Cronbach's alpha. A secondary test was to include a marker variable, i.e., a variable that is theoretically unrelated to the studied concepts, in the statistical analyses (Podsakoff et al., 2003). If there is a relationship between the marker variable and any other variable, it would indicate a single respondent bias. We included an item concerning whether the site is predominantly supplying other businesses or consumers, and detected no relationship to other variables. While these two tests do not completely eliminate the risk of a single respondent bias, it shows that it is unlikely.

\section{Results}

The RQ was: what types of Lean practices are associated with the use of digital technologies in production? The RQ was answered using the regression analyses in Table 4. Model 1 shows that all five control variables are strongly associated with the use of digital technologies in production. Models 2-4 add one set of Lean practices (as independent variables) each, and all three sets of Lean practices are significantly associated with the dependent variable. There are remarkably small differences between the contributions of the three types of practices; all types are almost equally important in explaining the use of digital technologies.

Table 4 Regression models for Lean practices and the use of digital technology

\begin{tabular}{lcccc}
\hline Dependent $=$ use of digital technology & Model 1 & Model 2 & Model 3 & Model 4 \\
\hline (Constant, unstandardised) & $-1.54^{* *}$ & $-1.22^{* *}$ & $-.87^{* *}$ & $-0.76^{* *}$ \\
Control variables & & & & \\
$\quad$ LN size (employees) & $0.29^{* *}$ & $0.21^{* *}$ & $0.14^{* *}$ & $0.14^{* *}$ \\
$\quad$ Use of industrial robots/automation & $0.27^{* *}$ & $0.21^{* *}$ & $15^{* *}$ & $0.12^{* *}$ \\
$\quad$ Assembly-based industry (dummy) & $0.12^{* *}$ & $0.09^{*}$ & 0.06 & 0.05 \\
South Europe (dummy) & 0.06 & 0.07 & 0.03 & 0.01 \\
East Europe (dummy) & 0.03 & $0.09^{*}$ & 0.07 & $0.09^{*}$ \\
Lean practices & & & & \\
Flow-oriented manufacturing & & $0.27^{* *}$ & $0.31^{* *}$ & $0.33^{* *}$ \\
$\quad$ Work organisation & & & $0.26^{* *}$ & $0.28^{* *}$ \\
$\quad$ Human resource management & & & $0.24^{* *}$ \\
Model statistics & & & \\
R & & & 0.29 & 0.40 \\
Adjusted $\mathrm{R}^{2}$ & 0.23 & 0.28 & 0.34 & 0.39 \\
Change in $\mathrm{R}^{2}$ & & $0.06^{* *}$ & $0.06^{* *}$ & $0.05^{* *}$ \\
F value & $32.7^{* *}$ & $36.7^{* *}$ & $40.8^{* *}$ & $44.9^{* *}$ \\
$\mathrm{~N}$ & 548 & 548 & 548 & 548 \\
\hline
\end{tabular}

Notes: ${ }^{\mathrm{p}}<0.05, * * \mathrm{p}<0.01$, standardised beta coefficients. 
The contributions of three control variables are significant in the first model, whereas the significance for assembly-based industry disappears when including Lean variables. The regression models thus suggest that Lean practices have a far larger impact on the use of digital technology than type of industry, which is further corroborated by the significant increase in $\mathrm{R}^{2}$. Use of industrial robots and/or automation in production is strongly associated with the use of (other) digital technologies. This is not surprising, as firms inclined to use one set of technologies are likely to be more inclined towards the use of other technologies too. Neither of the two country control variables East (Croatia and Slovenia) and South (Portugal and Spain) shows much impact on the use of digital technologies.

The regression models in Table 4 show high values of $\mathrm{R}^{2}$. Moreover, the increase in $\mathrm{R}^{2}$ for each Lean variable added is also significant, showing that these variables provide significant additional explanatory power. The $\mathrm{F}$ values are also satisfactory for all models, and significant at $\mathrm{p}<0.01$, implying that the data fits the model well. Multicollinearity was checked, where the value needs to be below 10 (Cohen et al., 2003). The collinearity statistics for the model in Table 4 are consistently below 1.4. The residuals have been checked and they behave approximately randomly for all models.

\section{Discussion}

In our endeavour to explore the relationship between Lean practices and the use of digital technologies in production we formulated the following research question: what types of Lean practices are associated with the use of digital technologies in production?

The results in Table 4 reveal that all three types of Lean practices (flow orientation, work organisation and HRM) are strongly associated with firms' adoption of digital technologies. This result adds to the studies by Moyano-Fuentes et al. (2012) and Rossini et al. (2019). The former showed a link between IT systems and Lean methods, but focused on whether IT systems will enhance Lean, whereas the latter found a strong link between a broad range of technologies and Lean. We focused on whether Lean production can explain the adoption of digital technologies, and in addition to their study, we distinguished between different types of Lean, and specifically recognised that all three types of Lean are equally important. While the Moyano-Fuentes (2012) study focused solely on the automotive industry in Spain, and Rossini et al. (2019) focused mostly on Italy, we contribute a multi-country and multisector study on the topic. Our model takes into account the multidimensional nature of Lean, controlling for size, industry, region and technological maturity, with good fit and high explanatory power. It is also a multi-industry, multi-country survey with a high number of respondents. Nonetheless, we can confirm, and strengthen, the findings of both Moyano-Fuentes et al. (2012) and Rossini et al. (2019): there is indeed a strong link between Lean and digital technologies used in production.

The strong relationship implies that the studied firms seem to follow the advice provided by Zuehlke (2010), who argued that a Lean approach is needed for the implementation of new technologies. It indicates that the building of digitalisation capabilities may rely on possessing Lean capabilities. Thus this paper contributes to the debate about combining Lean and IT (Powell, 2013; Riezebos et al., 2009). Not only do the results show that it is perfectly possible to combine Lean and digitalisation (in terms 
of $\mathrm{VR} /$ simulation and administrative systems), this is indeed what firms are doing. We found no evidence of any contradiction between the two concepts.

In line with previous studies, such as Shah and Ward (2007) and Liker (2004), we found that the Lean practices contain highly interrelated elements. We identified three coherent components (Table 2) implying that firms do not implement individual practices but rather bundles of them. Our regression models in Table 4 utilised five control variables: size, type of industry, region and whether the firm had invested in robots and/or automation. As was predicted, all three control variables were significant, but only when the three Lean variables were not included. When the Lean variables were included, being part of an assembly-based industry was not associated with digitalisation. The regression model thus suggests that Lean practices are more strongly associated with the use of digital technology than type of industry. This is interesting since previous industry reports (European Commission, 2016; Strategy\&, 2013) have shown that company size and type of industry are major determinants on the level of digitalisation of firms. The investigation from PWC (Strategy\&, 2013) for example shows that digitalisation is mostly spread among the industries that we have characterised as assembly-based, while process-based industries are laggards. The reason for the discrepancy may be that this study measured production-related digitalisation, whereas Strategy\& (2013) also measured digitalisation in procurement and sales.

An underlying issue is how the identified strong links between Lean practices and the adoption of digital technologies can be understood and explained. What elements and features of Lean drive digitalisation? Two possible types of explanations can be contemplated: one theoretical and one more practical. A theoretical explanation is that Lean can serve as an absorptive capacity that lets the firms acquire, assimilate, transform and exploit external knowledge (Zahra and George, 2002). This ability is founded in previous investments in related knowledge or technology, and consists of both the knowledge assets and integration mechanisms (Cohen and Levinthal, 1990). We can speculate that since both Lean and the digital technologies in this study are production related, they share some underlying knowledge of production, i.e., there is a degree of knowledge relatedness (Riezebos et al., 2009; Rüttimann and Stöckli, 2016). Lean, as measured in this paper, also offers many integration mechanisms that are used for acquiring new knowledge and transforming it, such as value stream mapping and time set aside for creativity and innovation. It also offers mechanisms for dispersing the knowledge throughout the organisation, such as teamwork and shop floor segmentation. An efficient exploitation of the knowledge is indeed the goal of many of the Lean practices, such as standardised work instructions and task integration. It is thus reasonable to assume that Lean practices provide the absorptive capacity, in terms of knowledge assets and integration mechanisms, needed for acquiring, assimilating, transforming and exploiting new production-related digital technologies.

Some of the more empirical explanations for the strong link between Lean and digitalisation found in the literature (e.g., Sanders et al., 2016; Rüttimann and Stöckli, 2016) can be divided into four themes. The first theme is based on the character of Lean, specifically that the Lean concept drives towards more standardised and transparent processes allowing the combination of Lean and digital technology (Kolberg and Zühlke, 2015). Similarly, Zuehlke (2010) observed that digital systems tend to be too sequential as well as product and hardware-specific, whereas Lean aims at reducing complexity. It is thus conceivable that firms working with a Lean philosophy will simplify their processes 
to the extent that it becomes easier to select and implement digital technologies, and will probably choose or design more Lean digital systems too. This insight does explain why there is a strong linkage between two of the Lean dimensions that we measure, namely the ones concerning flow and work standardisation. But it does not explain why the HRM aspect is strongly related to digitalisation.

The second theme involves digitalisation being used as a method for controlling pull (Riezebos et al., 2009). This implies that production would first be arranged according to pull principles and then digital technologies would be brought in to assist the arrangement. Marvel and Standridge (2009) noted that whereas continuous improvement is used in order to perfect a process, simulations can achieve the same benefits faster. Thus companies aspiring for continuous improvement may be more likely to see the benefits associated with simulation methods. Similarly, Abdulmalek and Raigopal (2007) describe how simulations can be used for assessing benefits associated with Lean techniques. Firms with experience of implementing Lean techniques may be more likely to appreciate the benefits of such simulations.

As a third theme, Abu El-Ella et al. (2013) found that idea management systems support continuous improvement but that HRM-related factors are required too. Since HRM is a core part of Lean, we suggest that Lean firms are in a better position to implement idea management systems, which in turn can make the firm even leaner.

The fourth and final theme relates to the strong linkages between Lean and digitalisation, depending on the features of the digital technologies. For instance, the studies by Kuehn (2006) argued that the digital factory provides more advanced and graphical technologies that help in analysing process variations, which is crucial when making production processes more Lean. Similarly, Mrugalska and Wyrwicka (2017) show how Lean integration deficits can be solved by digital technologies. This implies that digital technologies may well enhance the effectiveness of Lean initiatives, as also suggested by authors such as Moyano-Fuentes et al. (2012). Since this is probably known to firms, firms that have implemented more Lean techniques are set to benefit more from digitalisation, and thus are more inclined to invest in such technologies.

\section{Conclusions}

The study is initiated by the discussion on how the current implementation of advanced types of technologies, envisioned by programs such as Industry 4.0, relates to the implementation of Lean production practices. The purpose of the paper was to explore the relationship between the simultaneous use of Lean practices and the use of established digital technologies in manufacturing. Our main theoretical contribution is that three bundles of Lean practices, concerning production flow, work organisation and HRM, are strongly associated with firms' adoption of digital technologies in production by manufacturing firms. The relationship between the Lean practices and digital technologies is indeed much stronger than the five control variables company size, type of industry, region and use of automation/robots.

In the discussion section both a theoretical and a more practical explanation are provided. We suggest that Lean provides the firm with an absorptive capacity that helps to acquire, assimilate and exploit digital technologies. The more practical explanation consists of specific aspects of Lean that are connected with the use of specific digital technologies. 
A practical implication of the study is that Lean practices may be required for realising the promise of the digital factory, which is highly relevant for firms seeking to improve their productivity, and for policymakers concerned with industry development.

One suggestion for further research is to clarify the identified strong connections between Lean practices and digital technologies. We suggest that a high level of Lean implementation is likely a good foundation for an increased use of digital technologies in manufacturing, but exactly what the 'optimal' implementation sequence of Lean and digitalisation is, is beyond the scope of this study. Perhaps a maturity model could be developed to assist academics and practitioners in this regard? This mature model could also be linked to performance, which was also not covered by this study. A final suggestion for further research concerns whether there is as strong a link between Lean and the technologies envisioned by Industry 4.0 as the ones found in this study.

\section{Acknowledgements}

We greatly acknowledge the contribution of the EMS team. They include, but are not limited to: Angela Jäger (Fraunhofer ISI), Bernhard Dachs (Austrian Institute of Technology), Karl-Heinz Leitner (Austrian Institute of Technology), Wolfram Rhomberg (Austrian Institute of Technology), Isabelle Royer (University of Lyon), Andrea Bikfalvi (University of Girona), Jasna Prester (University of Zagreb), Iztok Palcic (University of Maribor) and Susana Azevedo (University of Beira Interior).

\section{References}

Abdulmalek, F.A. and Rajgopal, J. (2007) 'Analyzing the benefits of Lean manufacturing and value stream mapping via simulation: a process sector case study', International Journal of Production Economics, Vol. 107, No. 1, pp.223-236.

Abu El-Ella, N., Stoetzel, M., Bessant, J. and Pinkwart, A. (2013) 'Accelerating high involvement: the role of new technologies in enabling employee participation in innovation', International Journal of Innovation Management, Vol. 17, No. 6, p.1340020 (22 pages).

Alawamleh, M., Ismail, L.B. and Mazzawi, R. (2018) 'Value chain and supply chain: which is more impacted by ERP systems?', International Journal of Services and Operations Management, Vol. 30, No. 4, pp.405-418.

Augusto, B.P. and Tortorella, G.L. (2019) 'Literature review on Lean healthcare implementation: assessment methods and practices', International Journal of Services and Operations Management, Vol. 32, No. 3, pp.285-306.

Barney, J. (1996) 'The resource-based theory of the firm', Organization Science, Vol. 7, No. 5, pp.477-501.

Barney, J., Wright, M. and Ketchen, D.J. (2001) 'The resource-based view of the firm: ten years after 1991', Journal of Management, Vol. 27, No. 6, pp.625-641.

Bhamu, J. and Sangwan, K.S. (2016) 'A framework for Lean manufacturing implementation', Int. J. Services and Operations Management, Vol. 25, No. 3, pp.313-333.

Bhutta, M.K.S., Egilmez, G., Chatha, K.A. and Huq, F. (2017) 'Survey of Lean management practices in Pakistani industrial sectors', Int. J. Services and Operations Management, Vol. 28, No. 3, pp.309-334.

Bracht, U. and Masurat, T. (2005) 'The digital factory between vision and reality', Computers in Industry, Vol. 56, No. 4, pp.325-333. 
Buer, S.V., Strandhagen, J.O. and Chan, F.T. (2018) 'The link between Industry 4.0 and Lean manufacturing: mapping current research and establishing a research agenda', International Journal of Production Research, Vol. 56, No. 8, pp.2924-2940.

Cocca, P., Marciano, F., Alberti, M. and Schiavini, D. (2019) 'Leanness measurement methods in manufacturing organisations: a systematic review', International Journal of Production Research, Vol. 57, Nos. 15-16, pp.5103-5118.

Cohen, J., Cohen, P., West, S. and Aiken, L. (2003) Applied Multiple Regression/Correlation: Analysis for the Behavioral Sciences, 3rd ed., Erlbaum, Mahwah, NJ.

Cohen, W.M. and Levinthal, D.A. (1990) 'Absorptive capacity: a new perspective on learning and innovation', Administrative Science Quarterly, Vol. 35, No. 1, pp.128-152.

Comrey, A.L.A. (1973) First Course in Factor Analysis, Academic Press, New York.

Dachs, B., Biege, S., Borowiecki, M., Lay, G., Jäger, A. and Schartinger, D. (2014) 'Servitisation of European manufacturing: evidence from a large scale database', The Service Industries Journal, Vol. 34, No. 1, pp.5-23.

Deloitte (2015) Industry 4.0. Challenges and Solutions for the Digital Transformation and Use of Exponential Technologies, Deloitte, Zurich.

Emiliani, M.L. (2006) 'Origins of Lean management in America', Journal of Management History, Vol. 12, No. 2, pp.167-184.

European Commission (2016) Digitalisering av den europeiska industrin. Hur vi kan utnyttja den inre marknadens alla möjligheter. Meddelande från kommissionen till Europaparlamentet, Brussels.

Fraunhofer ISI (2017) Project Description: European Manufacturing Survey [online] http://www.isi.fraunhofer.de/isi-en/i/projekte/fems.php (accessed 15 June 2017).

Galankashi, M.R. and Helmi, S.A. (2017) 'Assessment of Lean manufacturing practices: an operational perspective', International Journal of Services and Operations Management, Vol. 28, No. 2, pp.163-184.

Gandhi, P., Khanna, S. and Ramaswamy, S. (2016) 'Which industries are the most digital (and why)?', Harvard Business Review, Digital Article, 1 April [online] https://hbr.org/2016/04/achart-that-shows-which-industries-are-the-most-digital-and-why (accessed 21 October 2016).

Gecevska, V., Anisic, Z. and Stojanova, T. (2013) 'Lean product lifecycle management approach', International Journal of Industrial Engineering and Management, Vol. 4, No. 4, pp.207-214.

George, D. and Mallery, M. (2010) SPSS for Windows Step by Step: A Simple Guide and Reference, 17.0 Update, 10 th ed., Pearson, Boston.

Grant, R.M. (1996) 'Toward a knowledge-based theory of the firm', Strategic Management Journal, Vol. 17, No. Winter, pp.109-122.

Halgari, P., McHaney, R. and Pei, Z.J. (2011) 'ERP systems supporting lean manufacturing in SMEs', in Cruz-Cunha, M.M. (Ed.): Enterprise Information for Systems Business Integration in SMEs: Technological, Organizational, and Social Dimensions, Business Science Reference, Hershey, PA.

Hines, P., Holweg, M. and Rich, N. (2004) 'Learning to evolve: a review of contemporary Lean thinking', International Journal of Operations \& Production Management, Vol. 24, No. 10, pp.994-1011.

Hirsch-Kreinsen, H. (2016) 'Digitization of industrial work: development paths and prospects', Journal for Labour Market Research, not assigned to an issue, pp.1-14.

Imai, M. (1997) Gemba Kaizen. A Commonsense, Low-Cost Approach to Management, McGraw-Hill, New York.

Karlsson, C. and Åhlström, P. (1996) 'Assessing changes towards Lean production', International Journal of Operations \& Production Management, Vol. 16, No. 2, pp.24-41.

Khalili, A., Ismail, M.Y., Karim, A.N.M. and Daud, M.R.C. (2017) 'A comparative evaluation of contemporary models for Lean manufacturing practices', International Journal of Services and Operations Management, Vol. 28, No. 1, pp.26-45. 
Khan, S. (2016) Leadership in the Digital Age - A Study on the Effects of Digitalisation on Top Management Leadership, Master's thesis, Stockholm Business School, Stockholm University, Stockholm.

Kinkel, S. (2012) 'Trends in production relocation and backshoring activities: changing patterns in the course of the global economic crisis', International Journal of Operations \& Production Management, Vol. 32, No. 6, pp.696-720.

Kolberg, D. and Zühlke, D. (2015) 'Lean automation enabled by Industry 4.0 technologies', IFAC-PapersOnLine, Vol. 48, No. 3, pp.1870-1875.

Kuehn, W. (2006) 'Digital factory - integration of simulation from product and production planning towards operative control', Proceedings of the 20th European Conference on Modelling and Simulation, ECMS.

Lamming, R. (1996) 'Squaring Lean supply with supply chain management', International Journal of Operations \& Production Management, Vol. 16, No. 2, pp.183-196.

Liker, J. and Burr, K. (1999) 'Advanced planning systems as an enabler of Lean manufacturing', Automotive Manufacturing \& Production, Vol. 111, No. 2, pp.29-31.

Liker, J. and Morgan, J. (2006) 'The Toyota way in services: the case of Lean product development', Academy of Management Perspectives, Vol. 20, No. 2, pp.5-20.

Liker, J.K. (2004) The Toyota Way: 14 Management Principles from the World's Greatest Manufacturer, McGraw-Hill, New York.

Linting, M., Meulman, J.J., Groenen, P.J. and van der Koojj, A.J. (2007) 'Nonlinear principal components analysis: introduction and application', Psychological Methods, Vol. 12, No. 3, p.336.

Lu, Y. (2017) 'Industry 4.0: a survey on technologies, applications and open research issues', Journal of Industrial Information Integration, in press, DOI: 10.1016/j.jii.2017.04.005.

Marley, K.A. and Ward, P.T. (2013) 'Lean management as a countermeasure for 'normal' disruptions', Operations Management Research, Vol. 6, Nos. 1-2, pp.44-52.

Marvel, J.H. and Standridge, C.R. (2009) 'Simulation-enhanced Lean design process', Journal of Industrial Engineering and Management, Vol. 2, No. 1, pp.90-113.

McDermott, C.M. and Venditti, F.J. (2015) 'Implementing Lean in knowledge work: implications from a study of the hospital discharge planning process', Operations Management Research, Vol. 8, Nos. 3-4, pp.118-130.

Moyano-Fuentes, J., Martínez-Jurado, P.J., Maqueira-Marín, J.M. and Bruque-Cámara, S. (2012) 'Impact of use of information technology on Lean production adoption: evidence from the automotive industry', International Journal of Technology Management, Vol. 57, Nos. 1/2/3, pp.132-148.

Mrugalska, B. and Wyrwicka, M.K. (2017) 'Towards Lean production in Industry 4.0', Procedia Engineering, Vol. 182, pp.466-473.

Murman, E., Allen, T., Bozdogan, K., Cutcher-Gershenfeld, J., McManus, H., Nightingale, D., Rebentisch, E., Shields, T., Stahl, F., Walton, M., Warmkessel, J., Weiss, S. and Widnall, S. (2002) Lean Enterprise Value - Insights from MIT's Lean Aerospace Initiative, Palgrave Macmillan.

NIST/SEMATECH e-Handbook of Statistical Methods (2014) [online] http:/www.itl.nist.gov/ div898/handbook/ (accessed 6 April 2016).

Pettersen, J. (2009) 'Defining lean production: Some conceptual and practical issues', TQM Journal, Vol. 21, No. 2, pp.127-142.

Podsakoff, P.M., MacKenzie, S.B., Lee, J.Y. and Podsakoff, N.P. (2003) 'Common method biases in behavioral research: a critical review of the literature and recommended remedies', Journal of Applied Psychology, Vol. 88, No. 5, pp.879-903.

Powell, D. (2013) 'ERP systems in Lean production. New insights from a review of Lean and ERP literature', International Journal of Operations and Production Management, Vol. 33, Nos. 11/12, pp.1490-1510. 
Powell, D., Alfnes, E., Strandhagen, J.O. and Dreyer, H. (2013) 'The concurrent application of Lean production and ERP: towards and ERP-based Lean implementation process', Computers in Industry, Vol. 64, pp.324-335.

Rauch, E., Dallasega, P. and Matt, D.T (2016) 'The way from Lean product development (LPD) to smart product development (SPD)', Procedia CIRP, Vol. 50, pp.26-31.

Riezebos, J. and Klingenberg, W. (2009) 'Advancing Lean manufacturing, the role of IT', Computers in Industry, Vol. 60, pp.235-236.

Riezebos, J., Klingenberg, W. and Hicks, C. (2009) 'Lean production and information technology: connection or contradiction?', Computers in Industry, Vol. 60, pp.237-247.

Rossini, M., Costa, F., Tortorella, G.L. and Portioli-Staudacher, A. (2019) 'The interrelation between Industry 4.0 and Lean production: an empirical study on European manufacturers', The International Journal of Advanced Manufacturing Technology, Vol. 102, Nos. 9-12, pp.3963-3976.

Rowberry, S.P. (2015) 'Ebookness', Convergence: The International Journal of Research into New Media Technologies, 1 July, pp.1-18, DOI: 10.1177/1354856515592509.

Rüttimann, B.G. and Stöckli, M.T. (2016) 'Lean and Industry 4.0: twins, partners or contenders? A due clarification regarding the supposed clash of two production systems', Journal of Service Science and Management, Vol. 9, No. 6, pp.485-500.

Sanders, A., Elangeswaran, C. and Wulfsberg, J. (2016) 'Industry 4.0 implies Lean manufacturing: research activities in Industry 4.0 function as enablers for Lean manufacturing', Journal of Industrial Engineering and Management, Vol. 9, No. 3, pp.811-833.

Shah, R. and Ward, P.T. (2003) 'Lean manufacturing: context, practice bundles, and performance', Journal of Operations Management, Vol. 21, No. 2, pp.129-149.

Shah, R. and Ward, P.T. (2007) 'Defining and developing measures of lean production', Journal of Operations Management, Vol. 25, No. 4, pp.785-805.

Shenkar, O. and Li, J. (1999) 'Knowledge search in international cooperative ventures', Organization Science, Vol. 10, No. 2, pp.134-143.

Sony, M. (2018) 'Industry 4.0 and Lean management: a proposed integration model and research propositions', Production \& Manufacturing Research, Vol. 6, No. 1, pp.416-432.

Stork, A. (2015) Visual Computing Challenges of Advanced Manufacturing and Industrie 4.0, IEEE Computer Society, Technische Universität Darmstadt, Germany.

Strategy\& (2013) The 2012 Industry Digitization Index, Booz \& Company [online] http://www. strategyand.pwc.com/reports/2012-industry-digitization-index.

von Haartman, R. (2013) 'Do customers improve new product development efficiency? Revealing the impact of manufacturing-based absorptive capacity', International Journal of Business Performance Management, Vol. 14, No. 2, pp.149-165.

Yadav, O.P., Nepal, B.P., Rahaman, M.M. and Lal, V. (2017) 'Lean implementation and organizational transformation: a literature review', Engineering Management Journal, Vol. 29, No. 1, pp.2-16.

Zahra, S.A. and George, G. (2002) 'Absorptive capacity: a review, reconceptualization, and extension', Academy of Management Review, Vol. 27, No. 2, pp.185-203.

Zuehlke, D. (2010) 'SmartFactory - towards a factory-of-things', Annual Reviews in Control, Vol. 34, pp.129-138. 